\title{
PENGARUH BAURAN PEMASARAN JASA TERHADAP KEPUTUSAN KONSUMEN MENGINAP DI HOTEL PELANGI SEKAYU
}

\section{EFFECT OF SERVICES MARKETING MIX CONSUMER'S DECISION TO STAY AT PELANGI HOTEL SEKAYU}

\author{
Ellisyah Mindari \\ Sekolah Tinggi Ilmu Ekonomi Rahmaniyah \\ ellisyahmindari@gmail.com
}

\begin{abstract}
Abstrak: Penelitian ini bertujuan untuk mengetahui pengaruh bauran pemasaran jasa terhadap keputusan konsumen menginap, baik secara parsial maupun secara bersama-sama. Populasi dalam penelitian ini adalah konsumen yang menginap di Hotel Pelangi Sekayu. Sampel penelitian ini mempedomani saran Roscoe dalam melakukan analisis regresi ganda, maka jumlah anggota sampel minimal 10 kali dari jumlah variabel, yaitu 10 kali 8 variabel, artinya 80 responden. Metode analisis menggunakan alat analisis dengan bantuan program IBM SPSS Statistic 24. Hasil penelitian menunjukkan bahwa ada pengaruh yang positif dan signifikan bauran pemasaran jasa secara bersama-sama terhadap keputusan konsumen menginap dengan nilai $F_{\text {hitung }}(47,862)>F_{\text {tabel }}(2,140)$ dan nilai Sig $F$ $(0,000)<\alpha(0,05)$. Kemudian berdasarkan hasil uji t, tidak ada pengaruh yang signifikan variabel produk jasa terhadap keputusan menginap. Keputusan menginap di Hotel Pelangi Sekayu dipengaruhi secara signifikan oleh variabel tarif jasa, promosi, lokasi, orang, proses dan sarana fisik.
\end{abstract}

Kata kunci: Bauran Pemasaran Jasa, Keputusan Konsumen

Abstract: This study aims to analyze the effect of the services marketing mix consumer's decision to stay, either partially or collectively. The population in this study are consumers at Pelangi Hotel Sekayu. The sample of this research is based on Roscoe's suggestion in conducting multiple regression analysis, so the number of sample members is at least 10 times the number of variables, namely 10 times 8 variables, meaning 80 respondents. The analysis method uses analytical tools with the help of the IBM SPSS Statistic 24 Program. The results conclude that there is a positive and significant effect of the services marketing mix together on consumer decisions to stay with the value of $F_{\text {count }}(47.862)>F_{\text {table }}$ (2.140) and the Sig $F(0.000)<\alpha(0.05)$. Then based on the results of the t test, there is no significant effect of service product variables on the decision to stay. The decision to stay at Pelangi Hotel Sekayu is significantly influenced by the variable price, promotion, service location, people, processes and physical evidence.

Keywords: Services Marketing Mix, Consumer Decisions 


\section{PENDAHULUAN}

Perkembangan bisnis saat ini semakin hari semakin kompleks. Hampir setiap hari kita terlibat dengan kegiatan bisnis seperti pembelian barang dan atau jasa. Bermacam-macam kebutuhan hidup mulai dari kebutuhan fisik maupun psikologis harus kita penuhi setiap harinya. Di era globalisasi seperti ini persaingan bisnis harus transparan dan konsisten dalam memenuhi kebutuhan konsumennya.

Pada industri layanan, jasa pelayanan menjadi hal utama sebagai kekuatan dari eksisnya sebuah perusahaan dalam bersaing. Perusahaan yang bergerak di bidang jasa mempunyai peluang besar untuk berkembang dengan pesat jika perusahaan mempunyai kemampuan memenuhi harapan konsumennya.

Kotler dan Armstrong (2012: 224) mengemukakan services are a form of product that consist of activities, benefits or satisfactions offered for sale that are essentially intangible and do not resut in the ownership of anything (jasa adalah bentuk produk yang terdiri dari aktivitas, manfaat atau kepuasan yang ditawarkan untuk dijual dan pada dasarnya tak berwujud serta tidak menghasilkan kepemilikan akan sesuatu). Berbeda halnya dengan produk yang dapat dimiliki setelah transaksi terjadi.

Perkembangan industri perhotelan, khususnya di Indonesia semakin pesat. Bahkan terjadi ketimpangan yaitu jumlah yang tersedia melebihi jumlah yang diperlukan oleh konsumen. Oleh karena itu, setiap hotel berlombalomba dengan strategi pemasaran yang paling efektif untuk mendapatkan konsumen sebanyak mungkin, sehingga dapat dihasilkan laba yang maksimal dan meningkatkan pendapatan hotel.

Dalam membuat keputusan untuk bermalam di hotel, sebenarnya para pelanggan mempunyai beberapa persyaratan yang harus dipenuhi oleh pihak pengelola hotel yang berkaitan dengan fasilitas yang ditawarkan oleh hotel tersebut, misalnya lokasi hotel tersebut tidak jauh dari pusat kota ataupun berkaitan dengan pelayanan yang diberikan oleh hotel tersebut kepada para tamunya.

Kota Sekayu merupakan kota transit yang dilalui dalam melakukan perjalanan jauh ke kota lain ataupun ke provinsi lain. Hotel Pelangi sebagai salah satu hotel yang ada di Sekayu menyadari peluang ini untuk mendapatkan keuntungan. Banyaknya usaha yang sejenis mengakibatkan persaingan ketat yang tentunya memiliki pengaruh terhadap pendapatan Hotel Pelangi. Dalam mengantisipasi kondisi persaingan tersebut, maka Hotel Pelangi harus menganalisa bauran pemasaran jasa dan merancang strategi yang tepat guna meningkatkan tingkat hunian dan pendapatan tentunya.. 
Ratih Pratiwi dan Moh. Irfan Latif (2020) melakukan riset dengan tujuan untuk mengetahui bagaimana penerapan marketing mix terhadap minat menginap kembali di Hotel Grasia Semarang. Hasil penelitiannya menyimpulkan bahwa shariah marketing mix memiliki pengaruh signifikan terhadap minat menginap kembali pada Hotel Grasia Semarang. Produk/product, harga, tempat/saluran, promosi, proses, orang, bentuk fisik, sabar dan janji memiliki pengaruh dalam meningkatkan kecenderungan seseorang untuk membeli produk/ jasa.

Penelitian yang dilakukan oleh Qushairi Rawi dan Budhi Satrio (2020) dengan tujuan untuk mengetahui bauran pemasaran terhadap keputusan menginap di Hotel Andita Syariah Surabaya. Simpulan hasil pengujian mereka secara parsial menunjukkan variabel produk, variabel harga, variabel promosi, variabel bukti fisik dan variabel proses berpengaruh terhadap keputusan menginap.

Muhammad Iqbal melakukan penelitian dengan tujuan untuk mengetahui dan menganalisis pengaruh secara bersama-sama dan parsial bauran pemasaran (product, price, place, promotion, people, physical evidence and process) terhadap keputusan untuk menginap di hotel bintang lima di kota Palembang. Simpulan dari penelitiannya adalah semua variabel bauran pemasaran sama-sama mempunyai pengaruh terhadap keputusan menginap di hotel bintang lima. Secara parsial variabel produk, harga, promosi, orang dan bukti fisik berpengaruh signifikan terhadap keputusan menginap di hotel bintang lima, sedangkan variabel lokasi dan proses tidak berpengaruh signifikan terhadap keputusan menginap di hotel bintang lima. Variabel harga memiliki pengaruh yang dominan terhadap keinginan/keputusan konsumen/pelanggan/tamu untuk menginap di hotel bintang lima, khususnya Whyndam OPI dan The Excelton Hotel Palembang.

Penelitian yang saya lakukan bertujuan untuk mengetahui pengaruh bauran pemasaran jasa terhadap keputusan konsumen menginap di hotel Pelangi Sekayu, baik secara parsial maupun secara bersama-sama.

\section{TINJAUAN PUSTAKA}

Pemasaran sebagai proses
sosial dan manajerial untuk
memenuhi kebutuhan dan keinginan
konsumen melalui suatu pertukaran
(transaksi) untuk mendapatkan laba
(keuntungan). Memperhatikan
perkembangan pemasaran pada
dewasa ini, hendaknya kita
mempelajari manajemen pemasaran
sebagai ilmu dan seni dalam
mengelola pasar dengan target
kepuasan konsumen, sehingga
tercapai tujuan organisasi.

Pemasaran sebagai proses sosial dan manajerial untuk memenuhi kebutuhan dan keinginan konsumen melalui suatu pertukaran (transaksi) untuk mendapatkan laba (keuntungan). Memperhatikan perkembangan pemasaran pada dewasa ini, hendaknya kita mempelajari manajemen pemasaran sebagai ilmu dan seni dalam mengelola pasar dengan target tercapai tujuan organisasi. 


\section{Keputusan Pembelian}

Keputusan pembelian melalui proses jauh sebelum pembelian sesungguhnya dan bukan berarti berakhir ketika pembelian berlangsung, akan tetapi proses tersebut tetap berlanjut dalam waktu yang lama setelah pembelian. Tjiptono (2019: 53) mengemukakan bahwa proses keputusan pembelian dapat dikategorikan secara garis besar ke dalam tiga tahap utama: prapembelian, konsumsi dan evaluasi purnabeli.

Tahapan dalam proses keputusan pembelian yang sama juga dikemukakan oleh Kotler dan Keller (2012: 166), lima tahap tersebut adalah problem recognition, information search, evaluation of alternatives, purchase decision, and postpurchase behavior (pengenalan masalah, pencarian informasi, evaluasi alternatif, keputusan pembelian dan perilaku pascapembelian).

\section{Perilaku Konsumen}

Menurut Tjiptono (2019: 120), perilaku konsumen mencakup keputusan konsumen dalam hal pembelian, pemakaian dan penghentian pemakaian produk dan jasa. Perilaku konsumen meliputi beraneka bentuk produk dan dapat melibatkan banyak orang dengan berbagai peran berbeda.

Selanjutnya perilaku konsumsen menurut Daryanto (2011: 221) adalah tingkah laku dari konsumen, dimana mereka dapat mengilustrasikan pencarian untuk membeli, menggunakan, mengevaluasi dan memperbaiki suatu produk dan jasa mereka.

Kotler dan Keller (2012: 151) mendefinisikan perilaku konsumen sebagai the study of how individuals, groups, and organizations select, buy, use, and dispose of goods, services, ideas, or experiences to satisfy their needs and wants.

Peter dan Olson (2014: 6) menyatakan bahwa perilaku konsumen melibatkan pemikiran dan perasaan yang mereka alami serta tindakan yang mereka lakukan dalam proses konsumsi.

Perilaku konsumen adalah tindakan personal yang dilakukan oleh konsumen dalam proses keputusan pemenuhan kebutuhan akan barang dan atau jasa.

Faktor-faktor

yang Mempengaruhi Perilaku Konsumen

Menurut Kotler dan Amstrong (2012: 135), consumer purchases are influenced strongly by cultural, social, personal, and psychological characteristics Biasanya pemasar tidak dapat mengendalikan faktorfaktor semacam itu, tetapi mereka harus memperhitungkannya.

\section{Bauran Pemasaran}

Bauran pemasaran masih menjadi raja konsep pemasaran di era teknologi informasi seperti 
sekarang ini. Kotler dan Armstrong (2012: 51) mengemukakan the marketing mix is the set of tactical marketing tools that the firm blends to produce the response it wants in the target market (bauran pemasaran adalah kumpulan alat pemasaran taktis terkendali yang dipadukan perusahaan untuk menghasilkan respons yang diinginkan di pasar sasaran).

Ziethaml dan Bitner dalam

Sahabuddin (2019:

mengemukakan konsep bauran pemasaran tradisional (traditional marketing mix) terdiri dari $4 p$, yaitu produk (product), harga (price), promosi (promotion) dan tempat/lokasi (place). Kemudian untuk pemasaran jasa perlu bauran pemasaran yang diperluas (expanded marketing mix for services) dengan penambahana unsur non-traditional marketing mix, yaitu orang (people), proses (process) dan fasilitas fisik (physical evidence).

a. Produk Jasa (The Service Product)

Produk jasa menurut Sahabuddin (2019: 50) merupakan suatu kinerja penampilan, tidak berwujud dan cepat hilang, lebih dapat dirasakan daripada dimiliki serta pelanggan lebih dapat berpartisipasi aktif dalam proses mengkonsumsi jasa tersebut. Sesungguhnya pelanggan tidak membeli barang atau jasa, tetapi membeli manfaat dan nilai dari sesuatu yang dapat ditawarkan.

b. Tarif Jasa (Price)
Menurut Wulansari (2020: 177), harga didefinisikan sebagai sesuatu yang diberikan untuk menukar nilai dari sebuah produk atau layanan. Harga juga disebut dengan istilah-istilah lain di dalam masyarakat, seperti ongkos, tarif, komisi dan lain-lain.

\section{c. Promosi (Promotion)}

Promosi menurut Yuningsih dan Silaningsih (2020: 129) yaitu usaha yang dilakukan pemasar untuk mempengaruhi pihak lain agar berpartisipasi dalam kegiatan pertukaran.

d. Tempat/Lokasi Pelayanan (Place/Service Location)

Sahabuddin (2019: 53) juga mengemukakan bahwa untuk produk industri jasa, place diartikan sebagai tempat pelayanan jasa. Terdapat tiga macam tipe interaksi antara penyedia jasa dan pelanggan yang berhubungan dengan pemilihan lokasi, yaitu pelanggan mendatangi penyedia jasa, penyedia jasa mendatangi pelanggan atau penyedia jasa dan pelanggan melakukan interaksi melalui perantara.

e. Orang/Partisipan (People)

Pengertian orang menurut Zethaml, Bitner dan Gremler dalam Sahabuddin (2019: 59) adalah semua pelaku yang memainkan peranan dalam penyajian jasa, sehingga dapat mempengaruhi persepsi pembeli. Elemen-elemen dari people adalah pegawai perusahaan, konsumen dan konsumen lain dalam lingkungan jasa. Semua sikap dan tindakan 
karyawan, bahkan cara berpakaian karyawan mempunyai pengaruh terhadap persepsi konsumen atau keberhasilan penyampaian jasa (service ecounter).

\section{f. Proses (Process)}

Proses menurut Zethaml, Bitner dan Gremler dalam Sahabuddin (2019: 60) adalah semua prosedur aktual, mekanisme dan aliran aktivitas yang digunakan untuk menyampaikan jasa. Elemen proses ini mempunyai arti suatu upaya perusahaan dalam menjalankan dan melaksanakan aktifitasnya untuk memenuhi kebutuhan dan keinginan konsumennya.

g. Sarana Fisik (Physical Evidence)

Selanjutnya menurut Zethaml, Bitner dan Gremler dalam Sahabuddin (2019: 60), sarana fisik merupakan suatu hal secara nyata turut mempengaruhi keputusan konsumen untuk membeli dan menggunakan produk jasa yang ditawarkan. Unsur-unsur yang termasuk di dalam sarana fisik antara lain lingkungan fisik, dalam hal ini bangunan fisik, peralatan, perlengkapan, logo, warna dan barang-barang lainnya yang disatukan dengan service yang diberikan seperti tiket, sampul, label dan lain sebagainya.

Bauran pemasaran terdiri dari semua hal yang dapat dilakukan perusahaan untuk mempengaruhi permintaan produknya.

\section{Kerangka Pemikiran}

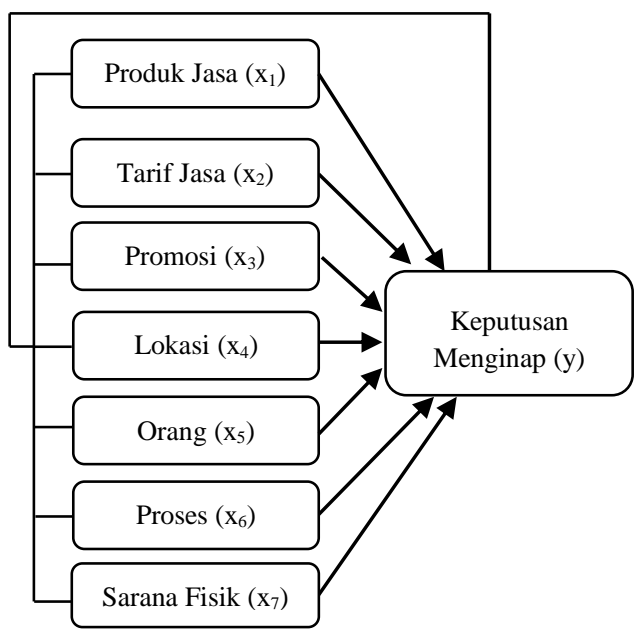

Gambar 1

Kerangka Pemikliran

\section{Hipotesis}

Adapun hipotesis dalam penelitian ini adalah:

1. Produk jasa, tarif jasa, promosi, lokasi, orang, proses dan sarana fisik secara bersama-sama mempengaruhi keputusan konsumen menginap di hotel Pelangi Sekayu.

2. Produk jasa, tarif jasa, promosi, lokasi, orang, proses dan sarana fisik secara parsial mempengaruhi keputusan konsumen menginap di hotel Pelangi Sekayu.

\section{METODOLOGI PENELITIAN}

\section{Desain Penelitian}

Penelitian ini bertujuan untuk menganalisis produk jasa $\left(\mathrm{x}_{1}\right)$, tarif jasa $\left(\mathrm{x}_{2}\right)$, promosi $\left(\mathrm{x}_{3}\right)$, lokasi $\left(\mathrm{x}_{4}\right)$, orang $\left(\mathrm{x}_{5}\right)$, proses $\left(\mathrm{x}_{6}\right)$ dan sarana fisik $\left(\mathrm{x}_{7}\right)$ terhadap keputusan 
menginap (y). Dengan demikian desain penelitian yang digunakan adalah korelasional. Penelitian ini mencoba mengumpulkan fakta dan data yang berkaitan dengan variabel yang menjadi perhatian dalam penelitian.

Dengan penelitian ini dapat diketahui bagaimana produk jasa, tarif jasa, promosi, lokasi, orang, proses dan sarana fisik mempengaruhi keputusan menginap, baik secara bersama-sama maupun secara parsial.

\section{Populasi dan Sampel}

Roscoe dalam Sugiyono (2019: memberikan saran-saran tentang ukuran sampel untuk penelitian seperti berikut ini:

1. Ukuran sampel yang layak dalam penelitian adalah antara 30 sampai dengan 500.

2. Bila sampel dibagi dalam kategori, maka jumlah anggota sampel setiap kategori minimal 30.

3. Bila dalam penelitian akan melakukan analisis dengan multivariate, maka jumlah anggota sampel minimal 10 kali dari jumlah variabel yang diteliti.

4. Untuk penelitian eksperimen yang sederhana, yang menggunakan kelompok eksperimen dan kelompok kontrol, maka jumlah anggota sampel masing-masing antara 10 sampai dengan 20 .
Berdasarkan saran Roscoe tersebut, maka jumlah anggota sampel minimal 10 kali dari jumlah variabel (ada 8 variabel, yaitu produk jasa, tarif jasa, promosi, lokasi, orang, proses dan sarana fisik dan keputusan menginap), yaitu 10 kali 8 variabel, artinya 80 responden.

\section{Sumber dan Teknik Pengumpulan}

Data

Penelitian ini menggunakan data primer dan data sekunder. Data dikumpulkan melalui kuesioner yang disebarkan yang bersifat tertutup di mana setiap pertanyaan / pernyataan sudah disediakan alternatif jawabannya, sehingga responden hanya memilih salah satu alternatif jawaban yang dianggap sesuai dengan pertanyaan/ pernyataan.

\section{Metode Analisis}

Data dalam penelitian ini diuji kualitasnya dengan uji validitas dan uji reliabilitas dengan menggunakan fasilitas perangkat lunak IBM SPSS Statistics 24 untuk melakukan uji validitas dan uji reliabilitas. Metode analisis kuantitatif digunakan untuk menganalisis data dalam penelitian ini dengan tahapan analisis regresi berganda, analisis determinan, uji serentak dan uji parsial.

\section{HASIL DAN PEMBAHASAN}

Pengujian Kuesioner

Pengujian Validitas Data 
Dari hasil uji validitas dengan menggunakan metode cronbach's alpha, untuk item-item variabel produk jasa $\left(\mathrm{x}_{1}\right)$, tarif jasa $\left(\mathrm{x}_{2}\right)$, promosi $\left(\mathrm{x}_{3}\right)$, lokasi $\left(\mathrm{x}_{4}\right)$, orang $\left(\mathrm{x}_{5}\right)$, proses $\left(\mathrm{x}_{6}\right)$ dan sarana fisik $\left(\mathrm{x}_{7}\right)$, keputusan menginap (y) dapat dilihat pada tabel berikut ini :

\section{Tabel 1}

\section{Hasil Uji Validitas}

\begin{tabular}{|c|c|c|c|c|}
\hline No. & Item & $\begin{array}{c}\text { Corrected } \\
\text { Item-Total } \\
\text { Correlation }\end{array}$ & $\begin{array}{c}\mathbf{r}_{\text {tabel }} \\
(\alpha=5 \%)\end{array}$ & $\begin{array}{l}\text { Hasil Uji } \\
\text { Validitas }\end{array}$ \\
\hline 1. & $\mathrm{X} 1 \_1$ & 0,582 & 0,223 & Valid \\
\hline 2. & x1_2 & 0,676 & 0,223 & Valid \\
\hline 3. & x1_3 & 0,580 & 0,223 & Valid \\
\hline 4. & x2_1 & 0,349 & 0,223 & Valid \\
\hline 5. & $x 2 \_2$ & 0,451 & 0,223 & Valid \\
\hline 6. & x2_3 & 0,584 & 0,223 & Valid \\
\hline 7. & x3_1 & 0,489 & 0,223 & Valid \\
\hline 8. & x3_2 & 0,400 & 0,223 & Valid \\
\hline 9. & x3_3 & 0,450 & 0,223 & Valid \\
\hline 10. & x4_1 & 0,441 & 0,223 & Valid \\
\hline 11. & x4_2 & 0,638 & 0,223 & Valid \\
\hline 12. & x4_3 & 0,578 & 0,223 & Valid \\
\hline 13. & x5_1 & 0,514 & 0,223 & Valid \\
\hline 14. & $x 5 \_2$ & 0,278 & 0,223 & Valid \\
\hline 15. & $x 5 \_3$ & 0,554 & 0,223 & Valid \\
\hline 16. & x5_4 & 0,490 & 0,223 & Valid \\
\hline 17. & x6_1 & 0,608 & 0,223 & Valid \\
\hline 18. & x6_2 & 0,309 & 0,223 & Valid \\
\hline 19. & x6_3 & 0,443 & 0,223 & Valid \\
\hline 20. & x6_4 & 0,397 & 0,223 & Valid \\
\hline 21. & x7_1 & 0,605 & 0,223 & Valid \\
\hline 22. & $x 7 \_2$ & 0,438 & 0,223 & Valid \\
\hline 23. & x7_3 & 0,315 & 0,223 & Valid \\
\hline 24. & y1 & 0,637 & 0,223 & Valid \\
\hline 25. & $\mathrm{y} 2$ & 0,322 & 0,223 & Valid \\
\hline 26. & $\mathrm{y} 3$ & 0,568 & 0,223 & Valid \\
\hline 27. & y4 & 0,399 & 0,223 & Valid \\
\hline 28. & y5 & 0,603 & 0,223 & Valid \\
\hline 29. & y6 & 0,654 & 0,223 & Valid \\
\hline 30. & y7 & 0,512 & 0,223 & Valid \\
\hline
\end{tabular}

Sumber : Hasil Pengolahan Data dengan IBM SPSS Statistics 24

Dari hasil pengolahan data menggunakan bantuan program IBM SPSS Statistics 24 menunjukkan hasil uji validitas dari setiap item pertanyaan/pernyataan variabel produk jasa $\left(\mathrm{x}_{1}\right)$, tarif jasa $\left(\mathrm{x}_{2}\right)$, promosi $\left(\mathrm{x}_{3}\right)$, lokasi $\left(\mathrm{x}_{4}\right)$, orang $\left(\mathrm{x}_{5}\right)$, proses $\left(\mathrm{x}_{6}\right)$, sarana fisik $\left(\mathrm{x}_{7}\right)$ dan keputusan menginap (y) tersebut valid pada taraf nyata $(\alpha)=5 \%$ yang berarti semua item pertanyaan / pernyataan yang ada pada instrumen tersebut dapat dijadikan sebagai alat ukur yang valid dalam analisis selanjutnya.

\section{Pengujian Reliabilitas Data}

Berdasarkan hasil uji reliabilitas dengan menggunakan metode cronbachs alpha untuk itemitem variabel produk jasa $\left(\mathrm{x}_{1}\right)$, tarif jasa $\left(\mathrm{x}_{2}\right)$, promosi $\left(\mathrm{x}_{3}\right)$, lokasi $\left(\mathrm{x}_{4}\right)$, orang $\left(\mathrm{x}_{5}\right)$, proses $\left(\mathrm{x}_{6}\right)$, sarana fisik $\left(\mathrm{x}_{7}\right)$ dan keputusan menginap (y) dapat dilihat pada tabel berikut ini :

\section{Tabel 2}

\section{Hasil Uji Reliabilitas}

\begin{tabular}{|c|l|c|c|c|}
\hline No. & Variabel & $\begin{array}{c}\text { Cronbach's } \\
\text { Alpha Item }\end{array}$ & $\begin{array}{c}\text { Nilai } \\
\text { Alpha }\end{array}$ & $\begin{array}{c}\text { Hasil Uji } \\
\text { Reliabilitas }\end{array}$ \\
\hline 1. & Produk Jasa & 0,776 & 0,600 & Reliabel \\
\hline 2. & Tarif Jasa & 0,647 & 0,600 & Reliabel \\
\hline 3. & Promosi & 0,636 & 0,600 & Reliabel \\
\hline 4. & Lokasi & 0,728 & 0,600 & Reliabel \\
\hline 5. & Orang & 0,673 & 0,600 & Reliabel \\
\hline 6. & Proses & 0,655 & 0,600 & Reliabel \\
\hline 7. & $\begin{array}{l}\text { Sarana } \\
\text { Fisik }\end{array}$ & 0,637 & 0,600 & Reliabel \\
\hline 8. & $\begin{array}{l}\text { Keputusan } \\
\text { Menginap }\end{array}$ & 0,796 & 0,600 & Reliabel \\
\hline
\end{tabular}

Dari hasil pengolahan data menggunakan bantuan program IBM SPSS Statistics 24 menunjukkan bahwa semua variabel yang akan digunakan dalam penelitian ini mempunyai nilai cronbach's alpha di atas 0,6. Dari hasil tersebut menunjukkan bahwa semua indikator tersebut dapat dijadikan sebagai alat ukur yang reliabel dalam analisis selanjutnya. 


\section{Analisis Regresi Berganda}

Analisis regresi berganda (multiple regression analysis) digunakan untuk melihat besaran pengaruh bauran pemasaran jasa (produk jasa $/ \mathrm{x}_{1}$, tarif $\mathrm{jasa} / \mathrm{x}_{2}$, promosi $/ \mathrm{x}_{3}, \quad$ lokasi $/ \mathrm{x}_{4}, \quad$ orang/ $\mathrm{x}_{5}$, proses $/ \mathrm{x}_{6}$ dan sarana fisik $/ \mathrm{x}_{7}$ ) terhadap keputusan menginap (y).
Hasil pengolahan data dengan menggunakan IBM SPSS Statistics 24 ditampilkan dalam tabel sebagai berikut :

Tabel 3

Coefficients

\begin{tabular}{|c|c|c|c|c|c|c|}
\hline & \multirow[t]{2}{*}{ Model } & \multicolumn{2}{|c|}{ Unstandardized Coefficients } & \multirow{2}{*}{$\begin{array}{c}\text { Standardized } \\
\text { Coefficients }\end{array}$} & \multirow[t]{2}{*}{$\mathrm{t}$} & \multirow[t]{2}{*}{ Sig. } \\
\hline & & $\mathrm{B}$ & Std. Error & & & \\
\hline \multirow[t]{8}{*}{1} & (Constant) & 8,121 & 1,693 & & 4,798 &, 000 \\
\hline & Produk Jasa &, 528 & ,286 &, 280 & 1,849 & ,069 \\
\hline & Tarif Jasa &,- 796 & ,205 &,- 387 & $-3,889$ &, 000 \\
\hline & Promosi &,- 650 & ,288 &,- 319 & $-2,256$ & 027 \\
\hline & Lokasi & $-1,317$ & ,264 &,- 669 & $-4,994$ &, 000 \\
\hline & Orang &, 734 & ,252 & ,439 & 2,913 & ,005 \\
\hline & Proses & ,965 & ,268 &, 580 & 3,601 &, 001 \\
\hline & Sarana Fisik & 1,710 & ,304 & ,831 & 5,628 &, 000 \\
\hline
\end{tabular}

a. Dependent Variable: Keputusan Menginap

Dari hasil regresi berganda dapat digambarkan persamaan regresi bergandanya sebagai berikut :

$\mathrm{Y}=\mathrm{a}+\mathrm{b}_{1} \mathrm{x}_{1}+\mathrm{b}_{2} \mathrm{x}_{2}+\mathrm{b}_{3} \mathrm{x}_{3}+\mathrm{b}_{4} \mathrm{x}_{4}+\mathrm{b}_{5} \mathrm{x}_{5}+\mathrm{b}_{6} \mathrm{x}_{6}+\mathrm{b}_{7} \mathrm{x}_{7}+\mathrm{e}$

$\mathrm{Y}=8,121+0,528 \mathrm{x}_{1}-0,796 \mathrm{x}_{2}-0,65 \mathrm{x}_{3}-1,317 \mathrm{x}_{4}+0,734 \mathrm{x}_{5}+0,965 \mathrm{x}_{6}+1,71 \mathrm{x}_{7}+\mathrm{e}$

Dari persamaan regresi berganda di atas dapat dijelaskan sebagai berikut:

- Konstanta sebesar 8,121 artinya jika produk jasa $\left(\mathrm{x}_{1}\right)$, tarif jasa $\left(\mathrm{x}_{2}\right)$, promosi $\left(\mathrm{x}_{3}\right)$, lokasi $\left(\mathrm{x}_{4}\right)$, orang $\left(\mathrm{x}_{5}\right)$, proses $\left(\mathrm{x}_{6}\right)$ dan sarana fisik $\left(\mathrm{x}_{7}\right)$ nilainya adalah 0 , maka keputusan menginap (y) nilainya adalah 8,121.

- Koefisien variabel yang bernilai positif artinya jika variabel independen lain nilainya tetap dan variabel yang bernilai positif tersebut mengalami kenaikan 1 satuan skor, maka keputusan menginap (y) mengalami peningkatan sebesar nilai koefisien tersebut dalam satuan skor. Koefisien bernilai positif artinya terjadi hubungan positif antara variabel yang bernilai positif tersebut dengan keputusan menginap (y), semakin meningkatnya variabel bernilai positif tersebut, maka semakin 
meningkat pula keputusan menginap (y).

- Koefisien variabel yang bernilai negatif artinya jika variabel independen lain nilainya tetap dan variabel yang bernilai negatif tersebut mengalami kenaikan 1 satuan skor, maka keputusan menginap (y) mengalami penurunan sebesar nilai koefisien tersebut dalam satuan skor. Koefisien bernilai negatif artinya terjadi hubungan negatif antara variabel yang bernilai negatif tersebut dengan keputusan menginap (y), semakin meningkatnya variabel bernilai negatif tersebut, maka semakin menurunnya keputusan menginap (y)

\section{Uji Koefisien Determinan}

Untuk menjawab pengaruh produk jasa $\left(\mathrm{x}_{1}\right)$, tarif jasa $\left(\mathrm{x}_{2}\right)$, promosi $\left(\mathrm{x}_{3}\right)$, lokasi $\left(\mathrm{x}_{4}\right)$, orang $\left(\mathrm{x}_{5}\right)$, proses $\left(\mathrm{x}_{6}\right)$ dan sarana fisik $\left(\mathrm{x}_{7}\right)$ secara bersama-sama terhadap keputusan menginap (y), yaitu menggunakan uji koefisien determinan sebagai berikut:

Tabel 4

Model Summary

\begin{tabular}{lr|r|r|r}
\hline Model & $\mathrm{R}$ & $\begin{array}{c}\mathrm{R} \\
\text { Square }\end{array}$ & $\begin{array}{c}\text { Adjusted } \\
\text { R Square }\end{array}$ & $\begin{array}{c}\text { Std. Error } \\
\text { of the } \\
\text { Estimate }\end{array}$ \\
\hline $1 \quad, 907^{\mathrm{a}}$ &, 823 &, 806 & 1,03899 \\
\hline
\end{tabular}

Dari tabel Model Summary di atas, terlihat bahwa nilai koefisien determinan ( $\mathrm{R}$ Square) adalah sebesar 0,823 (82,3\%). Hal ini berarti bahwa keputusan menginap (y) dapat dijelaskan oleh produk jasa $\left(\mathrm{x}_{1}\right)$, tarif jasa $\left(\mathrm{x}_{2}\right)$, promosi $\left(\mathrm{x}_{3}\right)$, lokasi $\left(\mathrm{x}_{4}\right)$, orang $\left(\mathrm{x}_{5}\right)$, proses $\left(\mathrm{x}_{6}\right)$ dan sarana fisik $\left(\mathrm{x}_{7}\right)$ sebesar 82,3\%, sedangkan sisanya $17,7 \%$ dijelaskan oleh faktor lain yang tidak termasuk dalam penelitian ini.

\section{Uji Hipotesis}

\section{Uji Serentak (Uji F)}

Menurut Priyatno (2010: 67), jika $F_{\text {hitung }} \geq \mathrm{F}_{\text {tabel}}$, maka $\mathrm{H}_{0}$ ditolak dan $\mathrm{H}_{\mathrm{a}}$ diterima, jika $\mathrm{F}_{\text {hitung }}<\mathrm{F}_{\text {tabel }}$, maka $\mathrm{H}_{0}$ diterima dan $\mathrm{H}_{\mathrm{a}}$ ditolak. Sedangkan $\mathrm{F}_{\text {tabel }}$ dengan taraf nyata $(\alpha)=5 \%$ dengan penyebut $\mathrm{dk}=(\mathrm{n}-\mathrm{k}-$ 1) $=(80-7-1)$ dan pembilang $(\mathrm{k}=7)$ adalah sebesar $\pm 2,140$.

\section{Tabel 5}

\begin{tabular}{|c|c|c|c|c|c|c|}
\hline \multicolumn{7}{|c|}{$\mathrm{ANOVA}$} \\
\hline \multicolumn{2}{|l|}{ Model } & $\begin{array}{l}\text { Sum of } \\
\text { Squares }\end{array}$ & Df & $\begin{array}{c}\text { Mean } \\
\text { Square }\end{array}$ & $\mathrm{F}$ & Sig. \\
\hline \multirow[t]{3}{*}{1} & Regression & 361,664 & 7 & 51,666 & 47,862 &, $000^{\mathrm{b}}$ \\
\hline & Residual & 77,723 & 72 & 1,079 & & \\
\hline & Total & 439,388 & 79 & & & \\
\hline \multicolumn{7}{|c|}{ a. Dependent Variable: keputusan menginap } \\
\hline \multicolumn{7}{|c|}{$\begin{array}{l}\text { b. Predictors: (Constant), sarana fisik, tarif jasa, promosi, } \\
\text { lokasi, produk jasa, orang, proses }\end{array}$} \\
\hline
\end{tabular}

Berdasarkan pada tabel di atas, maka dapat dilihat bahwa $F_{\text {hitung }}$ untuk variabel produk jasa $\left(\mathrm{x}_{1}\right)$, tarif jasa $\left(\mathrm{x}_{2}\right)$, promosi $\left(\mathrm{x}_{3}\right)$, lokasi $\left(\mathrm{x}_{4}\right)$, orang $\left(\mathrm{x}_{5}\right)$, proses $\left(\mathrm{x}_{6}\right)$ dan sarana fisik $\left(\mathrm{x}_{7}\right)$ terhadap keputusan menginap (y) adalah sebesar 47,862, maka $F_{\text {hitung }}(47,862)>F_{\text {tabel }}(2,140)$ yang berarti bahwa ada pengaruh produk jasa $\left(\mathrm{x}_{1}\right)$, tarif jasa $\left(\mathrm{x}_{2}\right)$, 
promosi $\left(\mathrm{x}_{3}\right)$, lokasi $\left(\mathrm{x}_{4}\right)$, orang $\left(\mathrm{x}_{5}\right)$, proses $\left(\mathrm{x}_{6}\right)$ dan sarana fisik $\left(\mathrm{x}_{7}\right)$ secara bersama-sama terhadap keputusan menginap (y), sehingga $\mathrm{H}_{0}$ ditolak dan $\mathrm{H}_{\mathrm{a}}$ diterima.

Nilai signifikan (Sig F) adalah sebesar 0,000 yang berarti Sig F $(0,000)<\alpha(0,05)$. Hal tersebut menggambarkan bahwa ada pengaruh yang signifikan produk jasa $\left(\mathrm{x}_{1}\right)$, tarif jasa $\left(\mathrm{x}_{2}\right)$, promosi $\left(\mathrm{x}_{3}\right)$, lokasi $\left(\mathrm{x}_{4}\right)$, orang $\left(\mathrm{x}_{5}\right)$, proses $\left(\mathrm{x}_{6}\right)$ dan sarana fisik $\left(\mathrm{x}_{7}\right)$ secara bersamasama terhadap keputusan menginap (y). Untuk lebih jelasnya, berikut ini akan disajikan gambar kurva uji $\mathrm{F}$ atas pengaruh produk jasa $\left(\mathrm{x}_{1}\right)$, tarif jasa $\left(\mathrm{x}_{2}\right)$, promosi $\left(\mathrm{x}_{3}\right)$, lokasi $\left(\mathrm{x}_{4}\right)$, orang $\left(\mathrm{x}_{5}\right)$, proses $\left(\mathrm{x}_{6}\right)$ dan sarana fisik $\left(\mathrm{x}_{7}\right)$ secara bersama-sama terhadap keputusan menginap (y) adalah sebagai berikut:

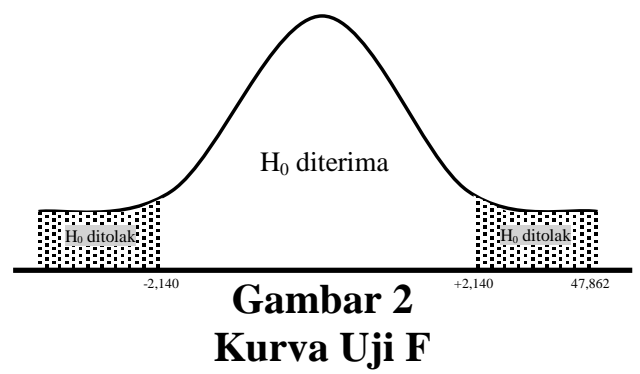

Dari hasil perhitungan uji $\mathrm{F}$ di atas, menggambarkan bahwa pada dasarnya produk jasa, tarif jasa, promosi, lokasi, orang, proses dan sarana fisik memberikan pengaruh yang cukup besar terhadap keputusan menginap di Hotel Pelangi Sekayu.

Hasil penelitian ini sejalan dengan hasil penelitian Ratih Pratiwi dan Moh. Irfan yang menyimpulkan bahwa shariah marketing mix memiliki pengaruh signifikan terhadap minat menginap kembali pada Hotel Grasia Semarang.

Sejalan pula dengan hasil penelitian Muhammad Iqbal yang menyatakan semua variabel bauran pemasaran sama-sama mempunyai pengaruh terhadap keputusan menginap di hotel bintang lima.

\section{Uji Parsial (Uji t)}

Untuk menjelaskan pengaruh produk jasa $\left(\mathrm{x}_{1}\right)$, tarif jasa $\left(\mathrm{x}_{2}\right)$, promosi $\left(\mathrm{x}_{3}\right)$, lokasi $\left(\mathrm{x}_{4}\right)$, orang $\left(\mathrm{x}_{5}\right)$, proses $\left(\mathrm{x}_{6}\right)$ dan sarana fisik $\left(\mathrm{x}_{7}\right)$ secara parsial terhadap keputusan menginap (y), digunakan uji hipotesis $\mathrm{t}$ dengan hasil pengolahan data pada tabel 3 .

Nilai $t_{\text {tabel }}$ dengan taraf nyata $(\alpha)=5 \%$, df $=(n-2)=(80-2)$ adalah sebesar $\pm 1,991$, maka dapat digambarkan bahwa:

1. Secara parsial produk jasa $\left(\mathrm{x}_{1}\right)$ tidak ada pengaruh yang signifikan terhadap keputusan menginap (y) di Hotel Pelangi Sekayu.

Hasil penelitian ini sesuai dengan pengamatan di lapangan. Produk jasa ini bisa dinikmati oleh semua orang karena hal yang terpenting adanya penawaran produk jasa bermalam/menginap untuk melepas penat dari kesibukan pekerjaan.

Namun, hasil penelitian ini berbeda dengan hasil penelitian sebelumnya yang 
dilakukan Qushairi Rawi dan Budhi Satrio yang hasil pengujian menunjukkan variabel produk berpengaruh terhadap keputusan menginap. Simpulan yang berbeda juga dinyatakan Muhammad Iqbal dalam penelitian bahwa secara parsial variabel produk berpengaruh terhadap keputusan menginap di hotel bintang lima.

2. Secara parsial tarif jasa $\left(\mathrm{x}_{2}\right)$, promosi $\left(\mathrm{x}_{3}\right)$, lokasi $\left(\mathrm{x}_{4}\right)$, orang $\left(\mathrm{x}_{5}\right)$, proses $\left(\mathrm{x}_{6}\right)$ dan sarana fisik $\left(\mathrm{x}_{7}\right)$ berpengaruh secara signifikan terhadap keputusan menginap (y) di Hotel Pelangi Sekayu

Hasil penelitian ini sejalan dengan hasil penelitian yang dilakukan Qushairi Rawi dan Budhi Satrio yang hasil pengujian mereka menunjukkan variabel harga, variabel promosi, variabel proses dan variabel bukti fisik berpengaruh terhadap keputusan menginap. Hanya saja mereka tidak menguji pengaruh varaibel lokasi dan variabel orang terhadap keputusan menginap.

Muhammad Iqbal dalam penelitian menyimpulkan hasil yang senada dengan Qushairi Rawi dan Budhi Satrio bahwa variabel harga, variabel promosi, varaibel orang dan variabel bukti fisik berpengaruh signifikan terhadap keputusan menginap. Namun, ada perbedaan dengan hasil uji terhadap variabel lokasi dan variabel proses yang secara parsial tidak berpengaruh secara signifikan terhadap keputusan menginap di hotel bintang lima.

\section{SIMPULAN}

Berdasarkan pembahasan hasil penelitian, disimpulkan bahwa ada pengaruh yang positif dan signifikan bauran pemasaran jasa secara bersama-sama terhadap keputusan konsumen menginap di Hotel Pelangi Sekayu. Akan tetapi secara parsial tidak ada pengaruh yang signifikan variabel produk jasa $\left(\mathrm{x}_{1}\right)$ terhadap keputusan menginap (y). Keputusan menginap di Hotel Pelangi Sekayu dipengaruhi secara signifikan oleh variabel tarif jasa $\left(\mathrm{x}_{2}\right)$, promosi $\left(\mathrm{x}_{3}\right)$, lokasi $\left(\mathrm{x}_{4}\right)$, orang $\left(\mathrm{x}_{5}\right)$, proses $\left(\mathrm{x}_{6}\right)$ dan sarana fisik $\left(\mathrm{x}_{7}\right)$.

\section{DAFTAR PUSTAKA}

Abdullah, Thamrin \& Francis Tantri. 2012. Manajemen Pemasaran. PT. RajaGrafindo Persada, Jakarta.

Daryanto. 2011. Sari Kuliah Manajemen Pemasaran. Satu Nusa, Bandung.

Hasan, M. Iqbal. 2013. Pokok-pokok Materi Statistik 1 (Statistik Deskriptif). PT. Bumi Aksara, Jakarta:

Kotler, Philip \& Gary Armstrong. 2012. Principles of Marketing 
$\left(14^{\text {th }} e d\right)$. Prentice Hall, New Jrsey.

Kotler, Philip \& Kevin Lane Keller. 2012. Marketing Management $\left(14^{\text {th }}\right.$ ed). Prentice Hall, New Jersey.

Kuncoro, Mudrajad. 2013. Metode Riset untuk Bisnis \& Ekonomi (Edisi 4). Erlangga, Jakarta.

Machali, Imam. 2015. Statistik itu Mudah, Menggunakan SPSS sebagai Alat Bantu Statistik. Lembaga Lada Kata, Yogyakarta.

McClave, James T., P. George Bendon \& Terry Sincich. 2011. Statistik untuk Bisnis dan Ekonomi (Edisi Kesebelas, Jilid 1). Erlangga, Jakarta.

Iqbal, Muhammad. 2020. Pengaruh Faktor-faktor Bauran Pemasaran Jasa terhadap Keputusan Konsumen untuk Menginap di Hotel Bintang Lima Kota Palembang. Integritas Jurnal Manajemen Profesional (IJMPro), Vol. 1 No. 2, 145-162.

Peter, J. Paul \& Jerry C. Olson. 2014. Perilaku Konsumen dan Strategi Pemasaran (Edisi 9, Buku 1). Salemba Empat, Jakarta.

Priyatno, Duwi. 2010. Paham Analisa Statistik Data dengan SPSS. PT. Buku Seru, Jakarta.

Rawi, Qushairi dan Budhi Satrio. 2020. Pengaruh Bauran
Pemasaran terhadap

Keputusan Menginap di Hotel Andita Syariah Surabaya. Jurnal Ilmu dan Riset Manajemen (JIRM), Vol. 8, No. 7, 1-17.

Pratiwi, Ratih dan Moh. Irfan Latif. 2020. Sharia Marketing Mix terhadap Minat Menginap Kembali di Hotel Grasia Semarang. Magisma: Jurnal Ilmiah Ekonomi dan Bisnis, Vol. 8, No. 1, 27-33.

Sahabuddin, Romansyah. 2019. Manajemen Pemasaran Jasa: Upaya untuk Meningkatkan Kepuasan Nasabah pada Industri Perbankan. Pustaka Taman Ilmu, Gowa.

Sekaran, Uma \& Roger Bougie. 2017. Metode Penelitian untuk Bisnis (Edisi 6, Buku 2). Salemba Empat, Jakarta.

Sinambela, Lijan Poltak. 2014. Metode Penelitian Kuantitatif untuk Bidang Ilmu Administrasi, Kebijakan Publik, Ekonomi, Sosiologi, Komunikasi dan Ilmu Sosial Lainnya. Graha Ilmu, Yogyakarta.

Sugiyono. 2019. Metode Penelitian Kuantitatif Kualitatif dan $R \& D$ (Edisi Kedua, Cetakan ke-1). Alfabeta, Bandung.

Sumarwan, Ujang. 2014. Perilaku Konsumen, Teori dan Penerapannya dalam Pemasaran (Edisi Kedua, 
Cetakan Kedua). Ghalia

Indonesia, Bogor.

. 2019. Analisis

Perilaku Konsumen dengan

Statistik Univariate. Riset

Pemasaran dan Konsumen

(13-48). IPB Press, Bogor.

Suryabrata, $\quad$ Sumadi. 2010.

Metodologi Penelitian. PT.

RajaGrafindo Persada, Jakarta.

Tjiptono, Fandy. 2019. Strategi

Pemasaran (Edisi 4). Andi,

Yogyakarta.

Wulansari, Ajeng Septiana. 2020.

Kebijakan Produk dan

Harga. Pengantar Bisnis

(163-182). Widina Bhakti

Persada, Bandung.

Yuningsih, Erni dan Endang

Silaningsih. 2020.

Manajemen Bisnis dan

Inovasi. Widina Bhakti

Persada, Bandung.

Zikmund, William G. \& Barry J.

Babin. 2011. Menjelajahi

Riset Pemasaran (Edisi 10,

Buku 1). Salemba Empat,

Jakarta. 